\title{
PLACING THE CZECH SHADOW BANKING SECTOR UNDER THE LIGHT
}

\author{
Martin Hodula, Martin Macháček, Aleš Melecký*
}

\begin{abstract}
The size of the shadow banking sector (SBS) has more than doubled in the Czech Republic over the last decade. This places a potential burden on policy makers. On the one hand, the SBS complements regular banking by expanding access to credit and investments, enabling better risk sharing and maturity transformation, and supporting market liquidity. On the other hand, SBS activities can put the stability of the financial system at risk and amplify its procyclicality by exacerbating the buildup of leverage and asset price bubbles. We implement a FAVAR model of the Czech economy to determine the impact of macroeconomic factors on the SBS. We find that the SBS: (i) is sensitive to changes in market interest rates and term spread; (ii) exhibits great procyclicality; (iii) can act as a complement to regular banking and satisfy some additional demand for credit. We also define some potential risks of continued growth of the SBS, linked to our empirical evidence.
\end{abstract}

Keywords: shadow banking, credit intermediation, Czech Republic, FAVAR JEL Classification: E44, G21, G28

\section{Introduction}

A decade ago, the Great Recession spotlighted both non-bank financial intermediation and off-balance activities of traditional banks, broadly referred to as "shadow banking". Although shadow banking activities can enhance the efficiency of the financial sector

* Martin Hodula, VSB - Technical University of Ostrava, Ostrava, Czech Republic (martin.hodula@vsb.cz); Martin Machacek, VSB - Technical University of Ostrava, Ostrava, Czech Republic (martin.machacek@vsb.cz); Ales Melecky, VSB -Technical University of Ostrava, Ostrava, Czech Republic (ales.melecky@vsb.cz). This paper greatly benefited from data support by the Czech National Bank. We would like to thank the seminar participants at the 2017 European Financial Systems and 16th International Conference on Finance and Banking, and seminar participants at the Poznan Summer School in Heterodox Economics. This research was supported by the 2017 Research Grant (SP2017/110) of VŠB - Technical University of Ostrava and the Czech Science Foundation grant GA16-13784S. 
under appropriate conditions, these activities were typically unregulated or lightly regulated in the pre-crisis era and significantly contributed to the worldwide economic turmoil of 2007-2009. As a result, academics and policymakers have become more interested in the determinants, opportunities and threats of shadow banking, and the number of relevant research studies has been growing fast. However, this trend is not apparent in the Czech Republic (CR) yet, although domestic shadow banking has a long and rich tradition.

Alternative (parallel) financial structures flourished even in socialist Czechoslovakia although they were represented by officially illegal loans and currency exchange provided by professional money changers (spivs, or "vekslaks" as they were called in Czech). In the first half of the 1990s there was a boom of conventional commercial banking which, due to the great speed of institutional transformation, resulted in several banking shocks and the macroeconomic downturn of 1997. Credit contraction by commercial banks during and after the banking crisis probably facilitated the birth of credit unions in the second half of the 1990s (see Hampl and Matoušek, 2000). However, these proliferating new financial intermediaries were only weakly regulated by the Bureau for Supervision over Credit Unions and suffered a big crisis in 1999-2000, with more than 70\% of deposits lost beyond recovery. As a result, an amending act had to be approved which limited transfer of credit unions' deposits to subsidiaries and made the supervision and regulation of this sector stricter (see Kuc and Teplý, 2015, for details on the history of credit unions in the CR). In 2006 credit unions finally started to be supervised by the Czech National Bank (CNB); nevertheless, other shadow banking entities in a narrow sense had already operated here since the beginning of the transformation. For instance, during the mass voucher privatization of 1992-1994, numerous investment funds were established the historical role and practice of which are still a matter of controversy. Moreover, pension funds appeared on the Czech market in the mid1990s and a very first domestic act on non-bank personal loans was approved in 2001.

Considering such vast historical experience accumulated, it is rather surprising that recent scholarly literature pays little, if any, attention to the size, development and impact of shadow banking in the CR. Despite the fact that five years have already passed since the CNB and the Czech Parliament expressed their opinion on the document "Green Paper, Shadow Banking" by the European Commission on the benefits, risks and regulation of shadow banking in Europe. Notwithstanding, the International Monetary Fund's influential study (IMF, 2014) shows that the banking sector constitutes over one-quarter of the total financial assets in the euro area. The forthcoming paper by Du et al. (2016) examines "a particular form of shadow banking business embedded in the operation of non-financial firms in China and transition economies in Central and Eastern Europe (CEE), in which firms borrow in order to lend". Although the authors include the CR in their multi-country sample, they do not provide estimates for most countries and the CR is not an exception. 
This paper thus aims to fill the gap in the literature on the Czech shadow banking sector (SBS) and contains a pilot estimate of the domestic shadow banking size and dynamics. We provide a sector decomposition to better understand the underlying trends and tendencies. Further, using a data-rich environment, we employ a factor-augmented vector autoregression (FAVAR) approach and explore the role of four potential macroeconomic drivers of shadow banking which are frequently discussed in the related literature (for a survey, see Duca, 2014). The shadow banking development is a worldwide reality (see Woodford, 2010, or Beck et al., 2016) and has a number of pros and cons (see, among others, Pozsar et al., 2013). We believe that a deeper understanding of shadow banking determinants may help domestic policy makers to mitigate related risks while benefiting from the main advantages.

The paper is organized as follows: Section 2 provides working definitions and some stylized facts about SBS; Section 3 lays down details on SBS size and dynamics in the CR; Section 4 describes model details and data sources; Sections 5 and 6 discuss our results and results of a sensitivity analysis and Section 7 concludes.

\section{Shadow Banking Definitions - A Brief Overview}

To this day, there is no consensus on the definition of shadow banking. At an institutional level, the first official definition was provided by the Financial Stability Board (FSB), which broadly described it as "the system of credit intermediation that involves entities and activities outside the regular banking sector" (FSB, 2011, p. 3) or under a narrower definition as "entities and activities outside the regular banking sector that raise systemic risk or regulatory arbitrage concerns" (FSB, 2012, p. 1). While the FSB provided a useful benchmark, its definitions have many shortcomings. First, in practice, many of shadow banking activities might originate within regular banks (see Pozsar and Singh, 2011); thus, we cannot conclusively describe shadow banking as activities "outside the regular banking sector". And second, the definitions are too broad, open to misinterpretations on an entity level. For these reasons, many alternative shadow banking definitions have been introduced over time, either by academic researchers or by policy-makers.

Nowadays, we may even attempt to group the definitions by their focus: (i) on the entity that carries out shadow banking activities (entity-based approach) or (ii) on the activities that the entity uses (activity-based approach). For instance, under the entity-based approach, Pozsar et al. (2013, p. 1) define shadow banks as "financial intermediaries that conduct maturity, credit, and liquidity transformation without access to central bank liquidity or public sector guarantees". Claessens and Ratkovski (2014, p. 4), on the other hand, propose to describe shadow banking within the activity-based approach as "all financial activities, except regular banking, which rely on a private or public backstop to operate". 
This captures activities such as securitization, collateral intermediation and wholesale funding arrangements. The IMF (2014) was among the first to combine the above approaches and suggested to consider both the financial entity and its market activities. We mark this as activity of entity-based approach. The IMF (2014, p. 68) states that "financing of bank- and non-bank financial institutions through noncore liabilities constitutes shadow banking, regardless of the entity that carries it out". Within the European Union, a first official note on the SBS was published by the European Commission (EC) in the form of a Green Paper (see EC, 2012). Since 2016, the European Systemic Risk Board (ESRB) has published a Shadow Banking Monitor, in which the ESRB also applies the activity of entity-based approach.

\section{Figure 1: EA Shadow Banking - Aggregate and Component Breakdown' (EUR trillions)}
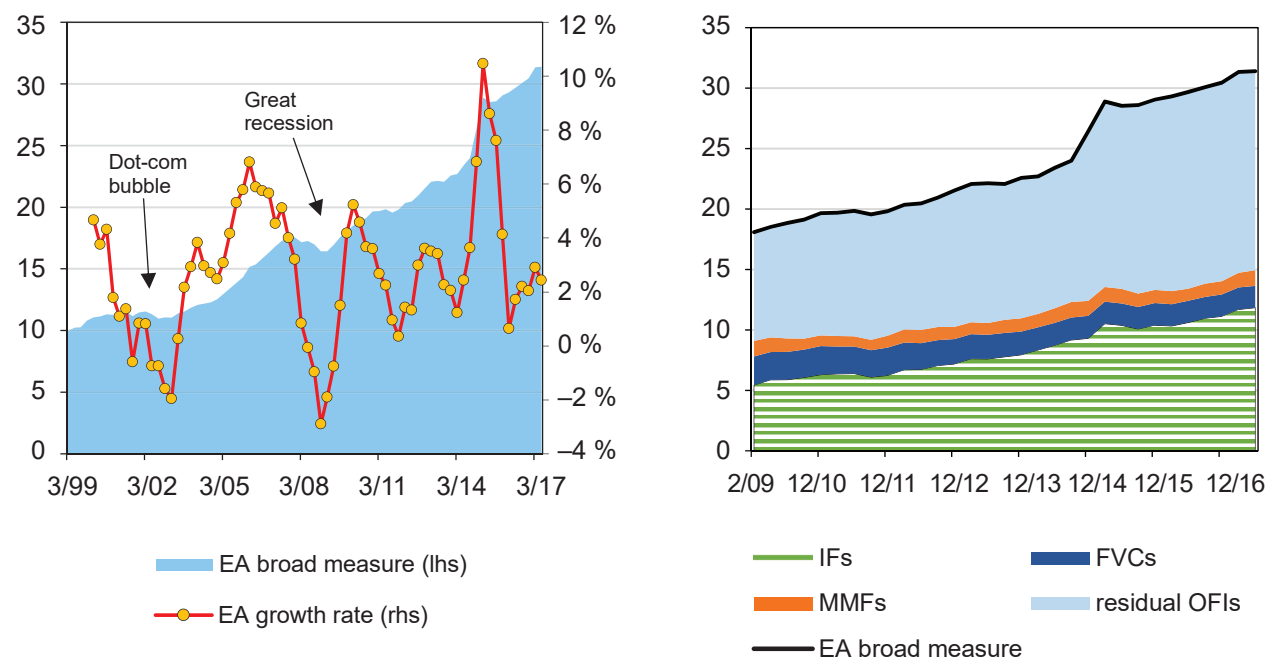

Note: Annual growth rates in the left-hand side chart are based on changes in outstanding amount at the end of a period.

Source: ECB/Eurosystem data, own processing

Another interesting aspect, when it comes to shadow banking definition, is the differentiation between a broad and a narrow perspective. For example, the FSB (2011) uses a broad perspective for defining a net-wide system and a narrower definition for evaluating regulatory options over individual entities. The ESRB employs only a broad measure of shadow banking in the EU and the EA due to remaining data gaps, comprising total assets of investment funds (IFs), including money market mutual funds (MMFs), and

1 The decomposition of the aggregate measure into components is limited by the data availability (ECB data are available since 2009). 
other financial institutions (OFIs), from which we may further extract financial vehicle corporations (FVCs). Figure 1 plots the SBS size in the EA, obtained by summing up the total assets of listed entities, accompanied by its dynamics. Like the regular banking, shadow entities appear to be susceptible to stressful market events, such as the dot-com bubble burst or the Great Recession. Still, they have almost tripled in size since 2004 and have expanded by almost $40 \%$ since 2012 . Nowadays, the SBS constitutes over one third of the aggregate financial sector in the EA.

\subsection{Some common shadow banking characteristics}

First off, we would like to highlight the fact that shadow banking activities do not automatically pose a threat to financial stability in general. The use of shadow banking services has a number of advantages: (i) securitization may benefit from risk diversification and even decrease market risks, (ii) securitization transforms illiquid assets (loans) into liquid securities, thereby increasing the liquidity of the entire financial system, (iii) through securitization, money lenders may significantly reduce the cost of credit (due to lower costs of capital, higher liquidity and lower risks) and (iv) the SBS is decentralized. However, these benefits may only prevail in an appropriate system structure (and regulatory environment), with adequate risk assessment of both the securities themselves and their transformations and transparency of products and participating institutions. Unless these conditions are met, the SBS's pitfalls will exceed the benefits.

While surveying the existing literature, we may provide some common characteristics of shadow banking entities which will serve in the upcoming country-specific analysis: (i) the activities are either focused around credit intermediation or they are associated with some forms of maturity and liquidity transformation and the use of leverage, (ii) there are no public safety nets placed in the system and no lender of the last resort, (iii) the entities and activities in the 'shadows' are less regulated than the regular banking institutions, and (iv) the absence of trivial regulation associated with the lack or weak regulatory arbitrageurs in the SBS may drive the financial system towards a point of systemic fragility.

Through the rest of the paper, we follow the activity of entity-based approach and use a broad measure to describe the SBS in the CR. To partially overcome the data limitations of the ECB/Eurosystem, we extract historical time series from the CNB data storage.

\section{Shadow Banking Structure in the Czech Republic}

Even though Czech banks use primarily a traditional business model and invest mostly in conservative securities, there are many other forms of financial intermediaries that are historically well established. These entities can be summarized into the following groups: investment funds (IFs), money market funds (MMFs) and other financial institutions 
(OFIs, comprised of other financial intermediaries, financial auxiliaries and captive financial institutions, and money lenders). The shadow banking activities in the $\mathrm{CR}$ are relatively simple since they do not involve long and complex chains of intermediation ${ }^{2}$. Nowadays, these activities are mostly concentrated around credit intermediation, liquidity and maturity transformations. Note that we exclude insurance corporations and pension funds (ICPFs) from the shadow market entities ${ }^{3}$, although they may carry out intermediation activities that can substitute or complement banking activities. This exclusion is based on the fact that ICFPs do not hold against the cross-check with common shadow banking characteristics (Section 2.1) as they are commonly regulated (OECD, 2015).

Figure 2 shows our estimate of the SBS size in the CR, which is the sum of the total assets of defined entities ${ }^{5}$. Compared to the size of regular banking assets, the size of shadow banking is rather small and constitutes roughly $20 \%$ of the total financial sector (end-of-2016 data). In general, the SBS grew at a steady pace prior to the last financial crisis and started to exhibit a downward-sloping trend after the crisis outburst. A high correlation of shadow and regular banking development during the period 2006-2009 was shattered after the crisis, with relatively greater fluctuations in the growth rate of shadow banking. In fact, the volatility of the SBS growth was two and a half times higher than the volatility of the regular banking sector growth in the post-crisis period. This suggests that the SBS may, on the one hand, react faster to changing conditions but, on the other hand, is more vulnerable to adverse economic development. After 2012, the SBS growth started to outperform that of the regular banking sector. To some extent, this is a natural by-product of the deepening of financial markets, with a concomitant rise in the rest of the economy and wealth of economic agents. However, if such a dynamic development continues, it may pose a risk to financial sector stability in the future.

The CNB's approach towards the shadow banking entities is based upon the European law and Decree no. 314/2013 Coll., which requires submitting of financial statements. The CNB oversees shadow banking entities and may take remedial measures or sanctions or, in the extreme case, remove their license. Still, a rapid expansion of the SBS might lower the control of credit dynamics in the economy and thus undermine the regulatory power of macroprudential policy.

2 Home Credit and Raiffeisenbank activities in 2003 and 2006, respectively, show an example of off-shore credit card conduit securitization transactions and may indicate that the Czech financial market is already prepared for cross-border securitizations (David and Šebesta, 2007).

3 This is rather common in the shadow banking literature, see for example Bakk-Simon et al. (2012, pp. 20), IMF (2014) and Pozsar et al. (2013), among others.

4 For example, the ESRB (2016) and Bakk-Simon et al. (2012) exclude ICPFs from their shadow banking estimates.

5 Note that data prior to 2008 are taken from the CNB data storage (ARAD archive) and were subject to different methodology that the post-2008 data. However, statistical tests conducted reject the presence of any structural breaks within the data. 


\section{Figure 2: Shadow vs. Regular Banking Sectors in the Czech Republic (CZK billions)}
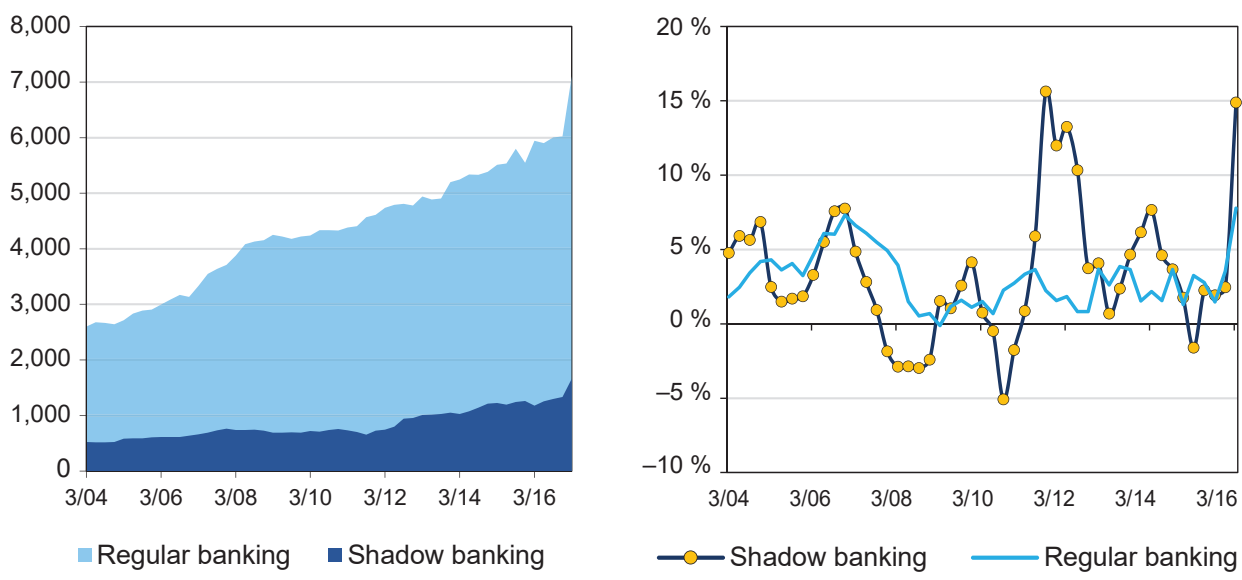

Source: CNB data, own processing

Further, we examine the SBS components in the CR in more detail (Figure 3). Nowadays, the SBS consists mostly of other financial institutions (80\%) and investment funds $(20 \%)$. Up until the Great Recession, the SBS expansion was led primarily by OFIs growth with an average pace rate around $4.5 \%$. OFIs consist of all nonbank financial corporations and quasi corporations engaged mainly in financial intermediation ${ }^{6}$. After the crisis, OFIs experienced rapid growth, mainly as a market reaction to an all-time low interest rate environment. The sudden surge at the end of 2016 may be associated with real income growth and increased household savings. This would suggest that economic agents allocate their resources not only to regular banking sector products but are starting to use more vividly products offered by OFIs.

Investment funds started to grow faster in reaction to the crisis, as they offer a way for potential investors to secure their money in longer-term and safer instruments. Nowadays, the growth of investments funds is mainly a reflection of structural changes in the Czech economy (a general increase in wealth) but it is also partly driven by the desire of economic agents to get higher returns on their resources compared to regular bank products. As of 2016, investment funds were the fastest-growing segment of the domestic financial sector. Despite the strong growth of investment funds, their share in the whole financial sector remains low. This is well captured by the results of decomposition

6 OFIs may be further decomposed into financial leasing companies (23\%), factoring and forfeiting companies $(2 \%)$, other lending companies $(4 \%)$ and the rest $(71 \%)$ - these shares are calculated based on end-of-2016 data. 
presented in Figure 3, where we weight the growth rate with the relative share of individual shadow banking components on the aggregate estimate.

\section{Figure 3: Czech Shadow Banking Sector - Component Breakdown (CZK billions)}
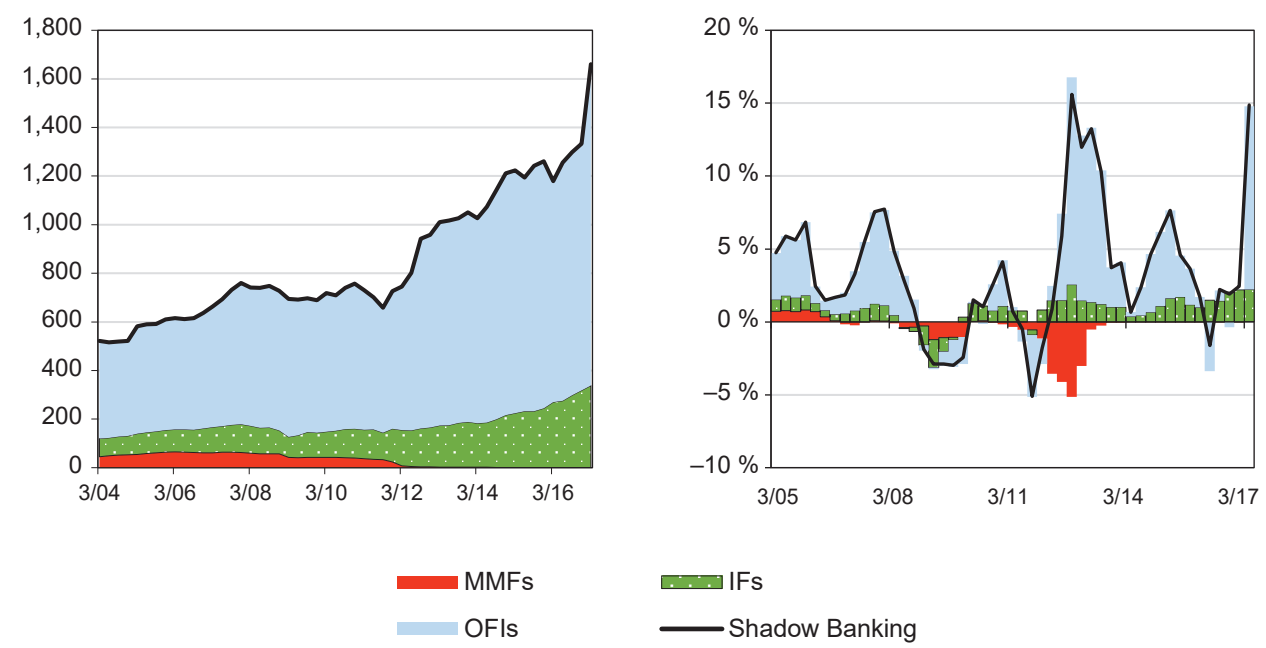

Source: CNB data, own processing

\section{Methodology}

In the empirical part of the paper, we take a closer look at the potential determinants of SBS development. To capture the SBS interactions with real economic environment, we estimate a FAVAR model described in Bernanke et al. (2005). The primary motivation for choosing the FAVAR model is to use the advantageous logic of VAR models, which are a theory-free way to let data speak about causality questions. The FAVAR model also addresses the dilemma arising from the information deficiency and the degree-of-freedom problem in traditional VAR models ${ }^{7}$.

In contrast to simple VAR model, the FAVAR model includes unobserved low-dimensional factors in the autoregression, thus reducing the information bias. The FAVAR model thus uses the advantages of a data-rich environment, while remaining tractable in terms of the number of parameters to be estimated. In our application, we specify an $M \times 1$ vector

7 The relatively small number of variables in a small VAR model may not be sufficient to properly identify shocks, which increases the risk of a biased estimate (see Bai et al., 2016, for detailed review). On the other hand, including more series in a VAR model is limited because of the loss of degrees of freedom. 
of macroeconomic and financial time series $Y_{t}$ and a $K \times 1$ vector of unobserved factors $F_{t}$. We assume that the joint dynamics of $F_{t}^{\prime}, Y_{t}^{\prime}$ are given by the following equation:

$$
\left[\begin{array}{l}
F_{t} \\
Y_{t}
\end{array}\right]=\Phi(L)\left[\begin{array}{l}
F_{t-1} \\
Y_{t-1}
\end{array}\right]+\varepsilon_{t},
$$

where $\Phi(L)$ is a lag polynomial and $\varepsilon_{t}$ is an error term with a zero mean and a covariance matrix Q. Equation (1) is a standard VAR model that can be interpreted as a reduced form of a linear rational-expectations model with both observed and unobserved variables. The unobserved variables make the model impossible to estimate. Therefore, we assume that there are additional informational time series $X_{t}$ linked to the unobservable factors $F_{t}$ and the observable factors $Y_{t}$ :

$$
X_{t}^{\prime}=\Lambda^{f} F_{t}^{\prime}+\Lambda^{y} Y_{t}^{\prime}+e_{t}^{\prime},
$$

where $\Lambda^{f}$ and $\Lambda^{y}$ are matrices of factor loadings and $e_{t}^{\prime}$ is a serially uncorrelated error term with a zero mean (innovation shock). Equation 2 captures the idea that both vectors $Y_{t}^{\prime}$ and $F_{t}^{\prime}$ are pervasive forces that might drive the common dynamics of $X_{t}^{\prime}$. This static representation of the dynamic factor model allows us to estimate the factors by principal components. As the static factors incorporate information from a large number of economic variables, the information set of the structural factor model is far greater than that of a standard VAR. Thus, it becomes unlikely that the information set of economic agents will be superior to our information set used. For details on the estimation procedure, please consult Appendix $\mathrm{B}^{8}$.

\subsection{Data and identification scheme}

Our vector $X_{t}$ for factor extraction consists of a balanced panel of 159 quarterly time series which represent the Czech economy and the rest of the world. They are drawn mainly from the CNB, Czech Statistical Office and ECB databases. The data span over the period 2005 Q1 - 2017 Q1. Generally, it is not required to perform any ex ante categorization of data but we can benefit from stacking the data into sub-groups in accordance with the different classes of economic variables for the sake of clarity of our computational process. We divide the set of variables into eight logical blocks (see Table 1). Note that prior to the estimation, the data were transformed to assure stationarity of the time series using natural logarithms and first differences ${ }^{9}$. By modelling the shadow banking

8 The FAVAR modelling framework is used in many economic applications, see for instance Boivin et al. (2009), Forni and Gambetti (2010) and Eickmeier and Hofmann (2013).

9 A more detailed description of the data is available upon request. 
dynamics in a data-rich environment, we control for real economy development, changes in the monetary policy, financial sector development and external influences.

To identify policy innovations, we divide our panel of variables into two groups: slow and fast-moving variables. Blocks describing the external environment, real economy, fiscal variables and prices are classified as slow-moving (in the same order as in Table 1). A slow-moving variable is one that is largely predetermined in the current period. The rest of the blocks are classified as fast-moving, which are assumed to be highly sensitive to contemporaneous economic news or shocks. The innovations are then identified recursively using this ordering. Note that the variables from which we extract the innovations are always ordered last in the covariance matrix (and treated as a factor on their own). This means that we assume each of the given innovations to affect our latent factors with a lag of one quarter ${ }^{10}$. Since we are working with a relatively scarce sample size, we must be careful to avoid a shortage of degrees of freedom; thus, we prefer to use a smaller model with a lower number of lags. The more sensitive exclusion based on the general-to-specific approach suggests that two lags are sufficient. Therefore, our baseline FAVAR model contains two lags.

Table 1: Sub-groups of Variables in the Dataset

\begin{tabular}{l|c|c}
\hline Data Sub-groups & Slow/Fast moving & Number of Variables \\
\hline External environment & (S) & 21 \\
\hline Real economy & (S) \\
\hline Labour market & (S) & 19 \\
\hline Government & (S) & 10 \\
\hline Prices and price expectations & (S) & 21 \\
\hline Interest rates and credits & (F) & 31 \\
\hline Financial sector & (F) & 19 \\
\hline Exchange rates & (F) & 6 \\
\hline
\end{tabular}

Note: Sub-groups highlighted in bold contains variables which are used as a source of an identified shock. These variables are never included in the dataset from which we extract the factors.

Source: Own processing

10 Note that the estimated system (given by Equation 1 and 2) may be used to draw out the responses of any series contained in the vector $X_{t}^{\prime}$. In this spirit, the identification scheme can be checked against the responses of many variables. 
Table 2: Description of Variables Used as Innovations

\begin{tabular}{l|l}
\hline $\begin{array}{l}\text { Innovation (shock) } \\
\text { Monetary expansion }\end{array}$ & Decrease in 3-month inter-bank rate (PRIBOR), average of observations \\
\hline Business cycle boom & Increase in real gross domestic product growth (seasonally adjusted) \\
\hline Term spread growth & $\begin{array}{l}\text { Increase in difference between 10Y government bond yields and 3M } \\
\text { PRIBOR, i.e., decrease in "preference of liquidity" }\end{array}$ \\
\hline Bank growth & Increase in regulated bank size growth (total assets) \\
\hline
\end{tabular}

Source: CNB data

We consider four macroeconomic and financial variables as potential shadow banking determinants (Table 2) and use these as sources of innovations. First, we consider effects of a change in the inter-bank rate, used as a proxy for monetary policy changes (monetary expansion $)^{11}$. However, given the fact that a generally low interest rate environment could make investors turn to shadow banks, we might just be picking up this "search for a yield motive". Second, we want to test the procyclical behaviour of shadow banks. For this purpose, we consider a change in the domestic demand and supply conditions, captured in a real GDP growth rate (business cycle boom). Third, we model a change in term spread to reflect liquidity or maturity transformation motives of banks in the CR (term spread growth). Fourth, we want to verify the potentially complementary character of the regular sector and the SBS (bank growth), which seems likely judging from the overall exposures of OFIs to regular banks (see Figure 1A in Appendix A).

\section{Results and Discussion}

For a clear presentation of our results, we provide impulse responses of the SBS to the four considered shocks. We plot the median responses to show the central tendency of the estimated response functions. The responses were normalized to entail 100 basis point (bp) innovations.

First, the SBS growth increases by up to $30 \mathrm{bps}$ as a result of a monetary expansion with the peak reaction in the sixth period after the shock. ${ }^{12}$ This finding also quantitatively corresponds to results obtained from recent DSGE models with a microfounded SBS (Verona et al., 2013). It shows that the search for a yield motive may be of some impor-

11 Similarly to how it is done in the CNB's forecasting system.

12 Similar results were obtained by the IMF (2014) and Cecchetti et al. (2017) for a large panel of economies and Barbu et al. (2016) for an EU-wide panel. However, the Czech Republic was not present in the three panel studies. Also, Barbu et al. (2016) form a highly unbalanced panel of countries and consider only money market mutual funds as representatives of the shadow banking sector. 
tance in the Czech banking sector. The lower yields motivate investors to search for more attractive returns in riskier places. Interestingly, we find no support for the controversial "waterbed effect" of monetary policy (Nelson et al., 2017; Herman et al., 2017), i.e., credit extension by banks and nonbanks responding in opposite directions to monetary shocks.

Second, we may state that the SBS reacts pro-cyclically to the business cycle development (following the shock, it grows by up to $50 \mathrm{bps}$ ). This result is in line with recent economic experience and it is confirmed by other experimental studies (see IMF, 2014; Brunnermeier and Sannikov, 2014). In boom years, the SBS transforms risky assets into short-term money-like instruments held by households, firms and institutional investors. However, liquidity and credit conditions sharply contract in the burst period (Moreira and Savov, 2017). Also, since the SBS offers an alternative source of funding to the real economy, we may expect that some portion of the additional demand for money will be satisfied by shadow banking entities. According to our results, the peak reaction of the SBS size to business cycle shock happens two years after the shock.

Figure 4: Shadow Banking Sector Responses to Defined Innovations
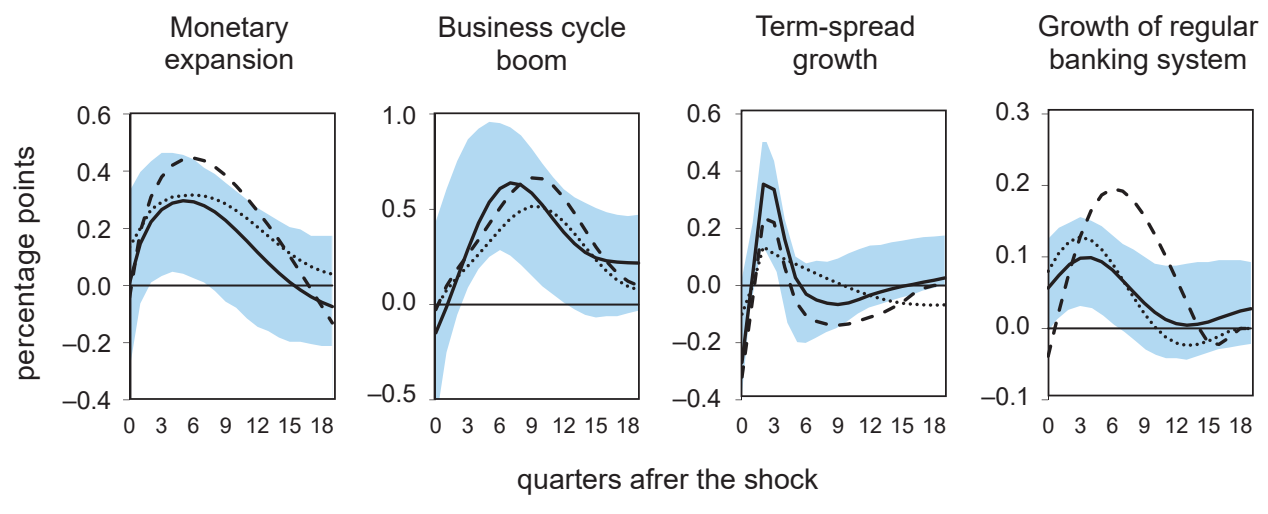

3 factors

5 factors - - - . 7 factors

$90 \%$ confidence bounds

Note: The baseline model is estimated using 3 factors and 2 lags; corresponding $90 \%$ probability bands are reported. The $y$-axis measures the strength of variables responses; the $x$-axis is quarters after the shock. Source: Own processing

Third, we identify a positive albeit very short and faint impact (30 bps) of increased term spread on SBS growth as the effect diminishes completely one year after. The deepening of the gap between the long-term and short-term interest rates is likely to alter the behaviour of households and firms, which may benefit from easy money offered 
by some OFIs. In addition, it shows that shadow banking entities may be used for liquidity and maturity transformations.

Last, we simulate a situation in which regular banks experience significant growth in terms of their aggregate balance. This situation may be well associated with increased demand for credit and other banking products. We find that regular banking sector growth is followed by a minor growth of the SBS (by up to $10 \mathrm{bps}$ ). This points to a somewhat complementary character between regular and shadow banks, which alone is evident from the significant exposures of shadow banks to the regular banking sector (see Appendix A). Also, it confirms that the increased demand for credits may be satisfied not only by regular banking products but also by shadow entities.

\section{Sensitivity Analysis by Shadow Banking Sector Components}

Since the analysis of the aggregate SBS provides only a limited amount of information, we proceed with an analysis of the individual components of the Czech SBS. Note that we add the ICPFs to this exercise, mainly to stress out the potential complementarities between the development of institutional investors and nonbank financial intermediaries ${ }^{13}$. The responses are cumulated over a three-year horizon.

First, after a monetary expansion, there is an obvious increase in total SBS growth driven by all its components, especially by the surge in investment fund assets (400 bps in three years). This highlights the existence of a search for a yield motive, under which the economic agents look for more profitable investment opportunities. On the contrary, the assets of ICPFs slightly decrease after the shock. ${ }^{14}$ Second, we observe the strongest reaction of the SBS and its components after the business cycle boom, which encourages flow of funds mainly into OFIs and MMFs. Also, we pick up an increase in ICPFs, most likely due to a general increase in income and wealth of economic agents. In turn, the interest in products of various investment funds decreases. This may be explained by the strong government support to pension funds through most of the sample period, which puts them ahead of investment funds. Third, the cumulative effect of term spread growth is rather insignificant at the aggregate level, even though the reactions of individual components are not negligible (but they offset each other). Again, the decrease in longterm investment funds and increasing shares in money market funds point to a search for a liquidity motive. Last, the reaction of the SBS to regular banking sector growth is

13 According to COM/STD/DAF (2015), more than one-third of the countries questioned consider ICPFs a part of the definition of shadow banking.

14 Our finding is consistent with the multi-country evidence by Cecchetti et al. (2017) except risktaking by insurance companies, which responds in the same direction to monetary policy in their paper. 
rather minor, which supports our suggestion presented in Section 3 above that the positive relationship of these two sectors was shattered after the crisis. The responses of individual components show that the increased demand for credits and banking products (associated with increase in regular banking assets) is also transmitted to OFIs.

\section{Figure 5: Sensitivity Analysis by Shadow Banking Sector Components}

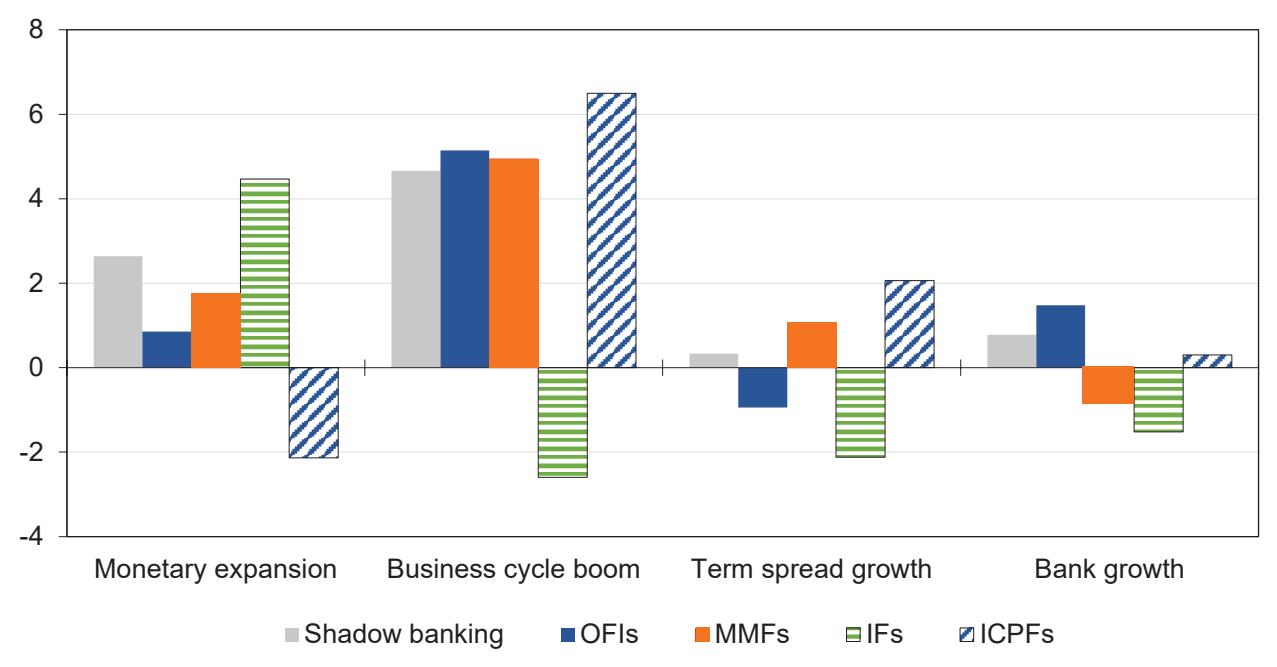

Source: Own processing

\section{Conclusion}

In the paper, we provide a pilot estimate of the shadow banking sector (SBS) size in the CR. Based on our original estimate, the SBS remains rather small compared to the Eurozone average with a share of $20 \%$ in the total financial sector assets. Nevertheless, the SBS exhibits great variation, especially in the post-crisis period where its growth even outperforms that of the regular banking sector. Further, we decompose the SBS into its components to better understand its evolution over time. In the empirical part of the paper, we construct a FAVAR model of the Czech economy and use the advantageous data-rich environment to examine the importance of four potential macroeconomic drivers of shadow banking dynamics.

First, we find some support to the search for a yield motive as the SBS generally expands following an expansionary monetary policy shock. This rapid expansion is caused by a surge in investment fund assets, suggesting that economic agents are more likely to seek higher profitability inside the SBS. Second, we find some evidence of SBS procyclicality 
as we detect the strongest positive median reaction and the highest accumulated response in a three-year period in the case of reaction to a business cycle boom. Generally, the SBS transforms risky assets into short-term money-like instruments, a function which will become more evident in boom years. The business cycle boom encourages flow of funds mainly into OFIs and MMFs. Third, we find only minor albeit positive impact of increased term-spread. This speaks in favour of the fact that shadow banking entities might be used for liquidity or maturity transformation. Also, the frequently forgotten policy of debt management may have some indirect impact on the SBS due to issuance of bills and bonds, which influence yield curve and therefore term spread. Fourth, we show that regular banking sector growth might be associated with a minor growth in the SBS. Two explanations are offered: the complementary character of services provided by regular and shadow banks and the fact that some of the increased demand for credit might be satisfied by not only regular but also shadow banks.

Overall, we can expect the SBS to continue to grow. Even though the SBS in the CR is currently rather small in an international comparison, its role within the financial market as well as in the entire economy cannot be neglected. To do this fact justice, we provide some potential risks stemming from the continued growth of shadow banking, linked to out empirical evidence: (i) accommodative monetary policy may support SBS expansion which, in turn, might endanger the stability of the financial sector due to the lack of any safety nets within the sector. This channel adds another portion of potential conflicts to the monetary-macroprudential policy interactions (Verona et al., 2013; Frait and Malovaná, 2017); (ii) the evident SBS procyclicality is troubling as adverse market developments may cause an increase in the number of withdrawals from investment funds, causing huge losses in the economy; (iii) the existence of joint exposures between the regular and SBS increases the systemic risk. 


\section{Appendix}

\section{A. Breakdown of Czech Financial Intermediaries}

\section{Figure 1A: Overall Market Shares and Total Exposures of Regular and Shadow Banks (CZK billions)}

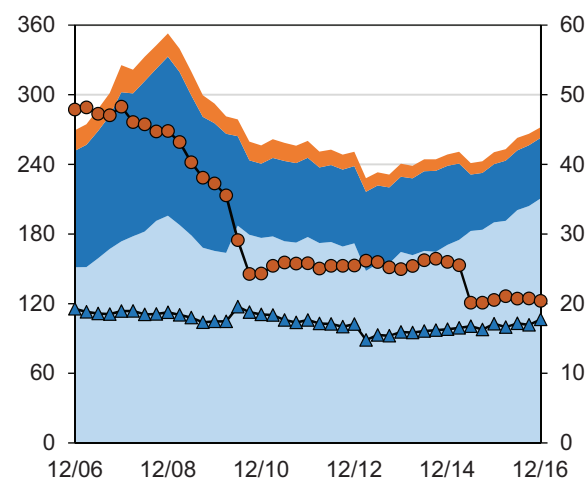

Other loans (Ihs)

Consumer loans to households (Ihs)

Loans to non-financial corporations (lhs)

$\longrightarrow$ Market share of OFIs - consumer loans (rhs)

$\neg$ Market share of OFIs - loans to NFCs (rhs)

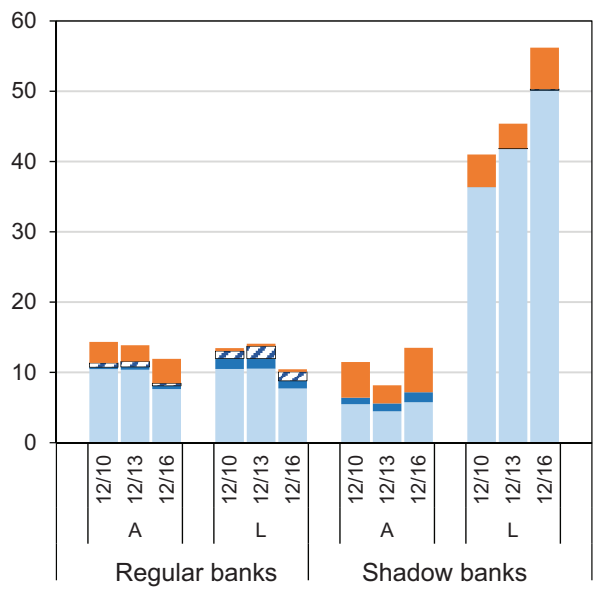

Exposures to OFIs

a Exposures to IPFCs

- Exposures to insurance comp.

Exposures to banks

Note: $A=$ assets, $L=$ liabilities. Shadow banks comprise other financial intermediaries only. IPFCs = investment and pension funds.

Source: CNB Financial Stability Report 2016/2017

\section{B. Details on the Estimation Procedure}

The model is estimated in five steps. First, all factor models require an initial step prior to the estimation to determine the optimal number of factors used. One possibility is to use the Bai-Ng information criterion to determine the number of factors present in the macroeconomic data vector $X_{t}$. However, as shown by Tuzcuoglu and Hoke (2016), different time spans might lead to different numbers of factors. Also, the Bai-Ng criterion does not solve the issue of how many factors we should include in the VAR model itself. We recommend employing a following general-to-specific approach: (i) estimate the model with a large number of factors; (ii) check the correlations of every single variable with the estimated factors; (iii) eliminate those factors which do not yield a statistically 
significant correlation with any group of variables in $X_{t}$; (iv) check that the simplified model remains congruent.

In our application, we have used from 7 to 3 factors and the model with 3 latent factors provides the highest explanatory power and its results are therefore reported in the main text. In Table 1A, we check the correlations of sub-groups of variables with the estimated factors. Visual inspection helps us to determine the actual interpretation of these factors. The first factor loads on real economic variables, coupled with prices. The positive correlations accumulated in the second factor correspond at most to credit and financial sector-related variables. The third factor explains the external development, which is of great importance to Czech economy. The remaining fourth and fifth factors are mostly insignificant in terms of correlations, which only justifies estimating the FAVAR model with just three latent factors.

Table 1A: Correlations Among Data and Estimated Factors

\begin{tabular}{|c|c|c|c|c|c|c|c|}
\hline Data Sub-groups & Factor 1 & Factor 2 & Factor 3 & Factor 4 & Factor 5 & Factor 6 & Factor 7 \\
\hline Real economy & 0.464 & 0.148 & -0.191 & -0.070 & -0.015 & -0.035 & 0.101 \\
\hline Labour market & 0.289 & 0.151 & 0.110 & -0.096 & 0.072 & 0.056 & -0.081 \\
\hline Government & 0.233 & -0.546 & -0.108 & -0.016 & 0.031 & 0.168 & -0.170 \\
\hline $\begin{array}{l}\text { Prices and price } \\
\text { expectations }\end{array}$ & 0.415 & -0.102 & 0.087 & 0.083 & 0.199 & 0.068 & 0.011 \\
\hline Interest rates and credits & -0.107 & 0.313 & 0.197 & 0.063 & -0.054 & -0.083 & 0.015 \\
\hline Financial sector & 0.006 & 0.240 & 0.188 & 0.108 & -0.069 & 0.081 & 0.043 \\
\hline Exchange rates & -0.153 & -0.031 & -0.015 & -0.014 & 0.025 & 0.134 & 0.034 \\
\hline External environment & 0.128 & 0.136 & 0.413 & 0.210 & -0.004 & 0.091 & 0.071 \\
\hline Factor 1 & 1 & - & - & - & - & - & - \\
\hline Factor 2 & 0.068 & 1 & - & - & - & - & - \\
\hline Factor 3 & 0.006 & -0.061 & 1 & - & - & - & - \\
\hline Factor 4 & 0.031 & 0.057 & -0.056 & 1 & - & - & - \\
\hline Factor 5 & 0.023 & -0.013 & -0.011 & 0.002 & 1 & - & - \\
\hline Factor 6 & 0.019 & -0.008 & -0.019 & 0.009 & 0.006 & 1 & - \\
\hline Factor 7 & -0.020 & 0.084 & -0.028 & 0.010 & 0.018 & 0.074 & 1 \\
\hline
\end{tabular}

Note: The table shows average correlations between sub-groups of variables with five estimated factors. Source: Own processing 
Second, we follow Stock and Watson (2002) and divide our panel of variables into two groups: slow- and fast-moving variables. Then, we use a two-step principal components approach, which is a nonparametric way of estimating the space spanned by the common components $C_{t}^{\prime}=\left(F_{t}^{\prime}, Y_{t}^{\prime}\right)$ in (2). The common components $C_{t}$ are estimated using the first $\mathrm{K}+\mathrm{M}$ principal components of $X_{t}$. Note that we impose the factor restriction (as in Bernanke et al., 2005), which identifies the factors against any rotations. $F_{t}^{\prime}$ is obtained as the part of the space covered by $C_{t}^{\prime}$ that is not covered by $Y_{t}$. In our application, we assume that the vector $Y_{t}$ holds only the specified innovations. As such, $Y_{t}$ may be treated as a separate factor with a pervasive effect on the rest of the economy $\left(X_{t}\right)$. In other words, for the two-step approach to work, our identification scheme requires first controlling for the part of $C_{t}^{\prime}$ that corresponds to the innovation in $Y_{t}$. A following regression is estimated in the process: $C_{t}^{\prime}=b_{F}{F_{t}^{\prime S}}^{\prime}+b_{Y} Y_{T}+e_{t}$ where $F_{t}^{\prime S}$ are slow-moving factors estimated from the slow-moving variables and $F_{t}^{\prime}=C_{t}^{\prime}-b_{Y}^{\prime} Y_{t}$. Third, the loading matrices are fitted into a VAR framework, estimated using the standard method, with $F_{t}$ being replaced by $F_{t}^{\prime}$. Fourth, the VAR is estimated and identified recursively using the ordering specified in the main text. Fifth, we construct confidence bands of the impulse response functions using a bootstrap-after-bootstrap technique proposed by Kilian (1998).

\section{FAVAR Dataset}

Table 2A shows all time series incorporated in the analysis. The abbreviations used stand for: CSO - Czech Statistical Office, CNB - Czech National Bank database ARAD, IMF - International Monetary Fund database, ECB - European Central Bank Statistical Data Warehouse, EIA - U.S. Energy Information Administration. The transformation codes (TC) are: 1 - no transformation; 2 - first difference of logarithm. SA denotes seasonally adjusted variables using CENSUS X13. S/F ranks variables as slow- or fastmoving in the estimation. 
Table 2A: Time Series Incorporated in the Analysis

\begin{tabular}{|c|c|c|c|c|c|c|c|}
\hline Group & No. & Series description & Unit & Source & Adj. & TC & $\mathbf{S} / \mathbf{F}$ \\
\hline \multirow{32}{*}{ 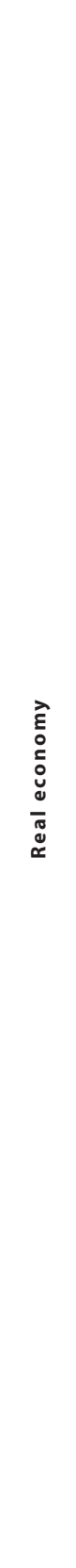 } & 1 & Industrial production index, industry total & $2010=100$ & CSO - Industry, energy & SA & 2 & $S$ \\
\hline & 2 & $\begin{array}{l}\text { Industrial production index, mining and } \\
\text { quarrying }\end{array}$ & $2010=100$ & CSO - Industry, energy & SA & 2 & $S$ \\
\hline & 3 & Industrial production index, manufacturing & $2010=100$ & CSO - Industry, energy & SA & 2 & S \\
\hline & 4 & $\begin{array}{l}\text { Industrial production index, electricity, gas, } \\
\text { steam and air conditioning supply }\end{array}$ & $2010=100$ & CSO - Industry, energy & SA & 2 & S \\
\hline & 5 & Sales from industrial activity, industry total & $2010=100$ & CSO - Industry, energy & SA & 2 & $S$ \\
\hline & 6 & $\begin{array}{l}\text { Sales from industrial activity, mining and } \\
\text { quarrying }\end{array}$ & $2010=100$ & CSO - Industry, energy & SA & 2 & S \\
\hline & 7 & Sales from industrial activity, manufacturing & $2010=100$ & CSO - Industry, energy & SA & 2 & $S$ \\
\hline & 8 & $\begin{array}{l}\text { Sales from industrial activity, electricity, gas, } \\
\text { steam and air conditioning supply }\end{array}$ & $2010=100$ & CSO - Industry, energy & SA & 2 & $S$ \\
\hline & 9 & Direct export sales, industry total & $2010=100$ & CSO - Industry, energy & SA & 2 & $\mathrm{~S}$ \\
\hline & 10 & Direct export sales, mining and quarrying & $2010=100$ & CSO - Industry, energy & SA & 2 & S \\
\hline & 11 & Direct export sales, manufacturing & $2010=100$ & CSO - Industry, energy & SA & 2 & $S$ \\
\hline & 12 & Domestic sales, industry total & $2010=100$ & CSO - Industry, energy & SA & 2 & S \\
\hline & 13 & Domestic sales, mining and quarrying & $2010=100$ & CSO - Industry, energy & SA & 2 & S \\
\hline & 14 & Domestic sales, manufacturing & $2010=100$ & CSO - Industry, energy & SA & 2 & $\mathrm{~S}$ \\
\hline & 15 & $\begin{array}{l}\text { Domestic sales, electricity, gas, steam and air } \\
\text { conditioning supply }\end{array}$ & $2010=100$ & CSO - Industry, energy & SA & 2 & S \\
\hline & 16 & New industrial orders, industry total & $2010=100$ & CSO - Industry, energy & SA & 2 & $\mathrm{~S}$ \\
\hline & 17 & Non-domestic new orders & $2010=100$ & CSO - Industry, energy & SA & 2 & S \\
\hline & 18 & Domestic new orders & $2010=100$ & CSO - Industry, energy & SA & 2 & S \\
\hline & 19 & Construction production index & $2010=100$ & CSO - Construction & SA & 2 & S \\
\hline & 20 & Construction production index, buildings & $2010=100$ & CSO - Construction & SA & 2 & $S$ \\
\hline & 21 & $\begin{array}{l}\text { Construction production index, civil } \\
\text { engineering works }\end{array}$ & $2010=100$ & CSO - Construction & SA & 2 & S \\
\hline & 22 & Retail trade receipts & $2010=100$ & CNB, ARAD & SA & 2 & S \\
\hline & 23 & Gross domestic product, market prices & Millions CZK & CSO - GDP & SA & 2 & S \\
\hline & 24 & GDP deflator & $2010=100$ & CNB, ARAD & SA & 2 & S \\
\hline & 25 & $\begin{array}{l}\text { Final consumption expenditures, total, current } \\
\text { prices }\end{array}$ & Millions CZK & CSO - GDP & SA & 2 & S \\
\hline & 26 & $\begin{array}{l}\text { Final consumption expenditures, households, } \\
\text { current prices }\end{array}$ & Millions CZK & CSO - GDP & SA & 2 & S \\
\hline & 27 & $\begin{array}{l}\text { Final consumption expenditures, government, } \\
\text { current prices }\end{array}$ & Millions CZK & CSO - GDP & SA & 2 & S \\
\hline & 28 & $\begin{array}{l}\text { Final consumption expenditures, non-profit } \\
\text { organisations, current prices }\end{array}$ & Millions CZK & CSO - GDP & SA & 2 & S \\
\hline & 29 & Gross capital formation, total, current prices & Millions CZK & CSO - GDP & SA & 2 & $S$ \\
\hline & 30 & Export, current prices & Millions CZK & CSO - GDP & SA & 2 & $S$ \\
\hline & 31 & Import, current prices & Millions CZK & CSO - GDP & SA & 2 & $\mathrm{~S}$ \\
\hline & 32 & Real gross domestic product & Millions CZK & CSO - GDP & SA & 2 & $S$ \\
\hline
\end{tabular}


Table 2A: (Continuation)

\begin{tabular}{|c|c|c|c|c|c|c|c|}
\hline Group & No. & Series description & Unit & Source & Adj. & TC & $\mathbf{S} / \mathbf{F}$ \\
\hline \multirow{19}{*}{ 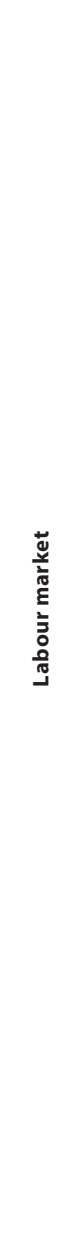 } & 33 & $\begin{array}{l}\text { Industry total, average number of persons } \\
\text { employed (ANPE) }\end{array}$ & $\begin{array}{l}\text { No. } \\
\text { of persons }\end{array}$ & CSO - Industry, energy & SA & 2 & $\mathrm{~S}$ \\
\hline & 34 & Industry, mining and quarrying, ANPE & $\begin{array}{l}\text { No. } \\
\text { of persons }\end{array}$ & CSO - Industry, energy & SA & 2 & $\mathrm{~S}$ \\
\hline & 35 & Industry, manufacturing, ANPE & $\begin{array}{l}\text { No. } \\
\text { of persons }\end{array}$ & CSO - Industry, energy & SA & 2 & $\mathrm{~S}$ \\
\hline & 36 & $\begin{array}{l}\text { Industry, electricity, gas, steam and air } \\
\text { conditioning supply, ANPE }\end{array}$ & $\begin{array}{l}\text { No. } \\
\text { of persons }\end{array}$ & CSO - Industry, energy & SA & 2 & S \\
\hline & 37 & $\begin{array}{l}\text { Industry total, average gross nominal wage } \\
\text { (AGNW) }\end{array}$ & $\begin{array}{l}\text { CZK per } \\
\text { person }\end{array}$ & CSO - Industry, energy & SA & 2 & $\mathrm{~S}$ \\
\hline & 38 & Industry, mining and quarrying, AGNW & $\begin{array}{l}\text { CZK per } \\
\text { person }\end{array}$ & CSO - Industry, energy & SA & 2 & $S$ \\
\hline & 39 & Industry, manufacturing, AGNW & $\begin{array}{l}\text { CZK per } \\
\text { person }\end{array}$ & CSO - Industry, energy & SA & 2 & $S$ \\
\hline & 40 & $\begin{array}{l}\text { Industry, electricity, gas, steam and air } \\
\text { conditioning supply, AGNW }\end{array}$ & $\begin{array}{l}\text { CZK per } \\
\text { person }\end{array}$ & CSO - Industry, energy & SA & 2 & $\mathrm{~S}$ \\
\hline & 41 & $\begin{array}{l}\text { Construction total, average number of persons } \\
\text { employed (ANPE) }\end{array}$ & $\begin{array}{l}\text { No. } \\
\text { of persons }\end{array}$ & CSO-Construction & SA & 2 & $\mathrm{~S}$ \\
\hline & 42 & $\begin{array}{l}\text { Construction total, average gross nominal wage } \\
\text { (AGNW) }\end{array}$ & $\begin{array}{l}\text { CZK per } \\
\text { person }\end{array}$ & CSO - Construction & SA & 2 & S \\
\hline & 43 & Employees total, hours worked & $\begin{array}{l}\text { thousand } \\
\text { hours }\end{array}$ & CSO - GDP & SA & 2 & $\mathrm{~S}$ \\
\hline & 44 & Employees, Agriculture, forestry and fishing & $\begin{array}{l}\text { thousand } \\
\text { hours }\end{array}$ & CSO - GDP & SA & 2 & $\mathrm{~S}$ \\
\hline & 45 & $\begin{array}{l}\text { Employees, Manufacturing, mining and } \\
\text { quarrying and other industry }\end{array}$ & $\begin{array}{l}\text { thousand } \\
\text { hours }\end{array}$ & CSO - GDP & SA & 2 & $\mathrm{~S}$ \\
\hline & 46 & Employees, Construction & $\begin{array}{l}\text { thousand } \\
\text { hours }\end{array}$ & CSO - GDP & SA & 2 & $\mathrm{~S}$ \\
\hline & 47 & $\begin{array}{l}\text { Employees, Trade, transportation, } \\
\text { accommodation and food service }\end{array}$ & $\begin{array}{l}\text { thousand } \\
\text { hours }\end{array}$ & CSO - GDP & SA & 2 & $\mathrm{~S}$ \\
\hline & 48 & $\begin{array}{l}\text { Employees, Public administration, education, } \\
\text { health and social work }\end{array}$ & $\begin{array}{l}\text { thousand } \\
\text { hours }\end{array}$ & CSO - GDP & SA & 2 & $\mathrm{~S}$ \\
\hline & 49 & $\begin{array}{l}\text { General unemployment rate of the aged } 15 \\
\text { to } 64 \text { years }\end{array}$ & $\%$ & CNB, ARAD & SA & 1 & $\mathrm{~S}$ \\
\hline & 50 & Job Vacancies & thousand & CNB, ARAD & SA & 2 & $\mathrm{~S}$ \\
\hline & 51 & Unplaced job seekers & thousand & CNB, ARAD & SA & 2 & $\mathrm{~S}$ \\
\hline \multirow{10}{*}{ 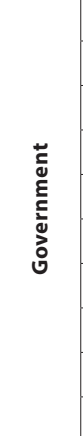 } & 52 & Government debt, total & Millions CZK & CSO - Government & SA & 2 & $\mathrm{~S}$ \\
\hline & 53 & Debt securities, total & Millions CZK & CSO - Government & SA & 2 & $\mathrm{~S}$ \\
\hline & 54 & Debt securities, short-term & Millions CZK & CSO - Government & SA & 2 & $\mathrm{~S}$ \\
\hline & 55 & Debt securities, long-term & Millions CZK & CSO - Government & SA & 2 & $\mathrm{~S}$ \\
\hline & 56 & Government loans, total & Millions CZK & CSO - Government & SA & 2 & $\mathrm{~S}$ \\
\hline & 57 & Government loans, short-term & Millions CZK & CSO - Government & SA & 2 & $\mathrm{~S}$ \\
\hline & 58 & Government loans, long-term & Millions CZK & CSO - Government & SA & 2 & $\mathrm{~S}$ \\
\hline & 59 & Debt interests paid & Millions CZK & CSO - Government & SA & 2 & $\mathrm{~S}$ \\
\hline & 60 & Government expenditures, total & Millions CZK & CSO - Government & SA & 2 & $\mathrm{~S}$ \\
\hline & 61 & Government revenue, total & Millions CZK & CSO - Government & SA & 2 & $\mathrm{~S}$ \\
\hline
\end{tabular}


Table 2A: (Continuation)

\begin{tabular}{|c|c|c|c|c|c|c|c|}
\hline Group & No. & Series description & Unit & Source & Adj. & TC & $\mathbf{S} / \mathbf{F}$ \\
\hline \multirow{21}{*}{ 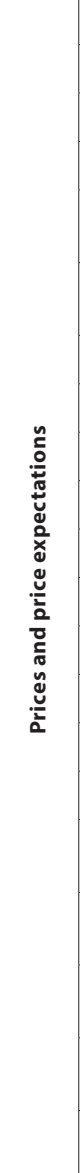 } & 62 & Consumer Price Index (CPI), total & $2015=100$ & CNB, ARAD & SA & 2 & $\mathrm{~S}$ \\
\hline & 63 & CPI, food and non-alcoholic beverages & $2015=100$ & CSO - Prices & SA & 2 & $\mathrm{~S}$ \\
\hline & 64 & CPI, alcoholic beverages, tobacco & $2015=100$ & CSO - Prices & SA & 2 & S \\
\hline & 65 & $\mathrm{CPI}$, clothing and footwear & $2015=100$ & CSO - Prices & SA & 2 & $\mathrm{~S}$ \\
\hline & 66 & $\begin{array}{l}\text { CPI, housing, water, electricity, gas and other } \\
\text { fuels }\end{array}$ & $2015=100$ & CSO - Prices & SA & 2 & $\mathrm{~S}$ \\
\hline & 67 & $\begin{array}{l}\mathrm{CPI} \text {, furnishings, household equipment, routine } \\
\text { maintenance of the house }\end{array}$ & $2015=100$ & CSO - Prices & SA & 2 & S \\
\hline & 68 & CPI, health & $2015=100$ & CSO - Prices & SA & 2 & $\mathrm{~S}$ \\
\hline & 69 & CPI, transport & $2015=100$ & CSO - Prices & SA & 2 & $\mathrm{~S}$ \\
\hline & 70 & CPI, communications & $2015=100$ & CSO - Prices & SA & 2 & $\mathrm{~S}$ \\
\hline & 71 & $\mathrm{CPI}$, recreation and culture & $2015=100$ & CSO - Prices & SA & 2 & $\mathrm{~S}$ \\
\hline & 72 & CPI, education & $2015=100$ & CSO - Prices & SA & 2 & S \\
\hline & 73 & $\mathrm{CPI}$, restaurants and hotels & $2015=100$ & CSO - Prices & SA & 2 & $\mathrm{~S}$ \\
\hline & 74 & CPI, miscellaneous goods and services & $2015=100$ & CSO - Prices & SA & 2 & $\mathrm{~S}$ \\
\hline & 75 & Industrial Producer Prices (IPP), total & $2015=100$ & CSO - Prices & SA & 2 & S \\
\hline & 76 & IPP, mining and quarrying & $2015=100$ & CSO - Prices & SA & 2 & $S$ \\
\hline & 77 & IPP, manufacturing & $2015=100$ & CSO - Prices & SA & 2 & $S$ \\
\hline & 78 & $\begin{array}{l}\text { IPP, electricity, gas, steam and air conditioning } \\
\text { supply }\end{array}$ & $2015=100$ & CSO - Prices & SA & 2 & S \\
\hline & 79 & $\begin{array}{l}\text { IPP, water supply; sewerage, waste management } \\
\text { and remediation activities }\end{array}$ & $2015=100$ & CSO - Prices & SA & 2 & $\mathrm{~S}$ \\
\hline & 80 & $\begin{array}{l}\text { Market services price indices in the business } \\
\text { sphere, total }\end{array}$ & $2005=100$ & CSO - Prices & SA & 2 & S \\
\hline & 81 & $\begin{array}{l}\text { Inflation expectations of non-financial } \\
\text { corporations and companies for the } 1 Y \text { horizon }\end{array}$ & $\%$ & CNB, ARAD & SA & 1 & $\mathrm{~F}$ \\
\hline & 82 & $\begin{array}{l}\text { Financial market inflation expectations for } 1 Y \\
\text { horizon }\end{array}$ & $\%$ & CNB, ARAD & SA & 1 & $\mathrm{~F}$ \\
\hline
\end{tabular}


Table 2A: (Continuation)

\begin{tabular}{|c|c|c|c|c|c|c|c|}
\hline Group & No. & Series description & Unit & Source & Adj. & TC & $\mathbf{S} / \mathbf{F}$ \\
\hline \multirow{31}{*}{ 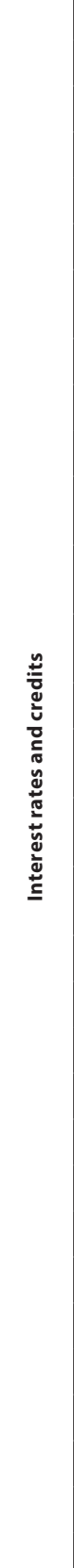 } & 83 & Repo rate - 2 weeks & $\%$ & CNB, ARAD & - & 1 & $\mathrm{~F}$ \\
\hline & 84 & PRIBOR 3M & $\%$ & CNB, ARAD & - & 1 & $\mathrm{~F}$ \\
\hline & 85 & PRIBOR 1Y & $\%$ & CNB, ARAD & - & 1 & $\mathrm{~F}$ \\
\hline & 86 & Government bond yield $2 \mathrm{Y}$ & $\%$ & CNB, ARAD & - & 1 & $\mathrm{~F}$ \\
\hline & 87 & Government bond yield $5 \mathrm{Y}$ & $\%$ & CNB, ARAD & - & 1 & $\mathrm{~F}$ \\
\hline & 88 & Government bond yield 10Y & $\%$ & CNB, ARAD & - & 1 & $\mathrm{~F}$ \\
\hline & 89 & $\begin{array}{l}\text { Bank interest rates on CZK-denominated loans, } \\
\text { households total }\end{array}$ & $\%$ & CNB, ARAD & - & 1 & $\mathrm{~F}$ \\
\hline & 90 & Bank interest rates, households, up to $1 \mathrm{Y}$ & $\%$ & CNB, ARAD & - & 1 & $\mathrm{~F}$ \\
\hline & 91 & Bank interest rates, households, up to $5 \mathrm{Y}$ & $\%$ & CNB, ARAD & - & 1 & $\mathrm{~F}$ \\
\hline & 92 & Bank interest rates, households, over $5 Y$ & $\%$ & CNB, ARAD & - & 1 & $\mathrm{~F}$ \\
\hline & 93 & $\begin{array}{l}\text { Bank interest rates, households consumer } \\
\text { credit - total }\end{array}$ & $\%$ & CNB, ARAD & - & 1 & $\mathrm{~F}$ \\
\hline & 94 & $\begin{array}{l}\text { Bank interest rates, households for house } \\
\text { purchase - total }\end{array}$ & $\%$ & CNB, ARAD & - & 1 & $\mathrm{~F}$ \\
\hline & 95 & $\begin{array}{l}\text { Bank interest rates, households other loans - } \\
\text { total }\end{array}$ & $\%$ & CNB, ARAD & - & 1 & $\mathrm{~F}$ \\
\hline & 96 & Bank interest rates, non-financial corporations & $\%$ & CNB, ARAD & - & 1 & $\mathrm{~F}$ \\
\hline & 97 & $\begin{array}{l}\text { Bank interest rates, non-financial corporations, } \\
\text { up to } 1 Y\end{array}$ & $\%$ & CNB, ARAD & - & 1 & $\mathrm{~F}$ \\
\hline & 98 & $\begin{array}{l}\text { Bank interest rates, non-financial corporations, } \\
\text { up to } 5 Y\end{array}$ & $\%$ & CNB, ARAD & - & 1 & $\mathrm{~F}$ \\
\hline & 99 & $\begin{array}{l}\text { Bank interest rates, non-financial corporations, } \\
\text { over } 5 Y\end{array}$ & $\%$ & CNB, ARAD & - & 1 & $\mathrm{~F}$ \\
\hline & 100 & Monetary base, monthly average & Billions CZK & CNB, ARAD & - & 2 & $\mathrm{~F}$ \\
\hline & 101 & Monetary aggregate M1 & Millions CZK & CNB, ARAD & - & 2 & $\mathrm{~F}$ \\
\hline & 102 & Monetary aggregate $\mathrm{M} 2$ & Millions CZK & CNB, ARAD & - & 2 & $\mathrm{~F}$ \\
\hline & 103 & Loans to residents and non-residents - MFIs & Millions CZK & CNB, ARAD & - & 2 & $\mathrm{~F}$ \\
\hline & 104 & Loans to non-financial corporations - MFIs & Millions CZK & CNB, ARAD & - & 2 & $\mathrm{~F}$ \\
\hline & 105 & Loans to financial corporations - MFIs & Millions CZK & CNB, ARAD & - & 2 & $\mathrm{~F}$ \\
\hline & 106 & Loans to government & Millions CZK & CNB, ARAD & - & 2 & $\mathrm{~F}$ \\
\hline & 107 & Loans to households & Millions CZK & CNB, ARAD & - & 2 & $\mathrm{~F}$ \\
\hline & 108 & Loans, short-term (up to $1 Y$ ) & Millions CZK & CNB, ARAD & - & 2 & $\mathrm{~F}$ \\
\hline & 109 & Loans, medium-term (up to 5Y) & Millions CZK & CNB, ARAD & - & 2 & $\mathrm{~F}$ \\
\hline & 110 & Loans, long-term (over 5Y) & Millions CZK & CNB, ARAD & - & 2 & $\mathrm{~F}$ \\
\hline & 111 & Consumption loans, total & Millions CZK & CNB, ARAD & - & 2 & $\mathrm{~F}$ \\
\hline & 112 & Mortgages, total & Millions CZK & CNB, ARAD & - & 2 & $\mathrm{~F}$ \\
\hline & 113 & Other loans, total & Millions CZK & CNB, ARAD & - & 2 & $\mathrm{~F}$ \\
\hline
\end{tabular}


Table 2A: (Continuation)

\begin{tabular}{|c|c|c|c|c|c|c|c|}
\hline Group & No. & Series description & Unit & Source & Adj. & TC & $S / F$ \\
\hline \multirow{19}{*}{ 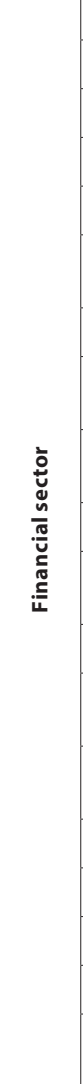 } & 114 & Capital adequacy ratio, total & $\%$ & CNB - non-public data & SA & 1 & $\mathrm{~F}$ \\
\hline & 115 & Leverage ratio, total & $\%$ & CNB - non-public data & SA & 1 & $\mathrm{~F}$ \\
\hline & 116 & Risk-weighted assets to total assets & $\%$ & CNB - non-public data & - & 1 & $\mathrm{~F}$ \\
\hline & 117 & Non-performing loans to total assets & $\%$ & CNB - non-public data & - & 1 & $\mathrm{~F}$ \\
\hline & 118 & Loans to total assets (LTA) & $\%$ & CNB - non-public data & - & 1 & $\mathrm{~F}$ \\
\hline & 119 & $\begin{array}{l}\text { Spread, defined as the difference between } 10 \mathrm{Y} \\
\text { gov. bonds yield and PRIBOR } 3 \mathrm{M}\end{array}$ & $\%$ & own calculation & - & 1 & $\mathrm{~F}$ \\
\hline & 120 & Composite indicator of sovereign stress & $0-1$ interval & $\mathrm{ECB}$ & - & 1 & $\mathrm{~F}$ \\
\hline & 121 & Financial cycle indicator & $0-1$ interval & $\begin{array}{l}\text { CNB - Financial Stability } \\
\text { Report 2016/2017 }\end{array}$ & - & 1 & $\mathrm{~F}$ \\
\hline & 122 & Index PX & value & $\begin{array}{l}\text { PSE, Prague Stock } \\
\text { Exchange }\end{array}$ & - & 2 & $\mathrm{~F}$ \\
\hline & 123 & MFI total assets & Millions CZK & CNB - ARAD & - & 2 & $\mathrm{~F}$ \\
\hline & 124 & House price index & $\begin{array}{l}\text { Index } 2010 \\
=100\end{array}$ & CSO - Prices & - & 2 & $\mathrm{~F}$ \\
\hline & 125 & Banks provisioning & value & CSO - Prices & - & 2 & $\mathrm{~F}$ \\
\hline & 126 & House price gap - CNB calculations & value & $\begin{array}{l}\text { CNB - Financial Stability } \\
\text { Report 2016/2017 }\end{array}$ & - & 1 & $\mathrm{~F}$ \\
\hline & 127 & $\begin{array}{l}\text { Overvaluation of commercial property prices - } \\
\text { CNB calculations }\end{array}$ & value & $\begin{array}{l}\text { CNB - Financial Stability } \\
\text { Report 2016/2017 }\end{array}$ & - & 1 & $\mathrm{~F}$ \\
\hline & 128 & Shadow banking sector, total assets & Millions CZK & CNB, ARAD & - & 2 & $\mathrm{~F}$ \\
\hline & 129 & Insurance companies and pension funds & Millions CZK & CNB, ARAD & - & 2 & $\mathrm{~F}$ \\
\hline & 130 & Money market funds & Millions CZK & CNB, ARAD & - & 2 & $\mathrm{~F}$ \\
\hline & 131 & Investment funds & Millions CZK & CNB, ARAD & - & 2 & $\mathrm{~F}$ \\
\hline & 132 & $\begin{array}{l}\text { Other financial intermediaries (financial vehicle } \\
\text { corporations) }\end{array}$ & Millions CZK & CNB, ARAD & - & 2 & $\mathrm{~F}$ \\
\hline \multirow{6}{*}{ 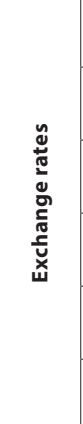 } & 133 & Real effective exchange rate & $\begin{array}{l}\text { Index } \\
2015=100\end{array}$ & CNB, ARAD & SA & 2 & $\mathrm{~F}$ \\
\hline & 134 & $\begin{array}{l}\text { Nominal exchange rate CZK/EUR, monthly } \\
\text { average }\end{array}$ & value & CNB, ARAD & - & 2 & $\mathrm{~F}$ \\
\hline & 135 & $\begin{array}{l}\text { Nominal exchange rate CZK/GBP, monthly } \\
\text { average }\end{array}$ & value & CNB, ARAD & - & 2 & $\mathrm{~F}$ \\
\hline & 136 & $\begin{array}{l}\text { Nominal exchange rate CZK/USD, monthly } \\
\text { average }\end{array}$ & value & CNB, ARAD & - & 2 & $\mathrm{~F}$ \\
\hline & 137 & $\begin{array}{l}\text { Nominal exchange rate CZK/JPY, monthly } \\
\text { average }\end{array}$ & value & CNB, ARAD & - & 2 & $\mathrm{~F}$ \\
\hline & 138 & Nominal effective exchange rate & $\begin{array}{l}\text { Index } \\
2015=100\end{array}$ & CNB, ARAD & - & 2 & $\mathrm{~F}$ \\
\hline
\end{tabular}


Table 2A: (Continuation)

\begin{tabular}{|c|c|c|c|c|c|c|c|}
\hline Group & No. & Series description & Unit & Source & Adj. & TC & $\mathbf{S} / \mathbf{F}$ \\
\hline \multirow{21}{*}{ 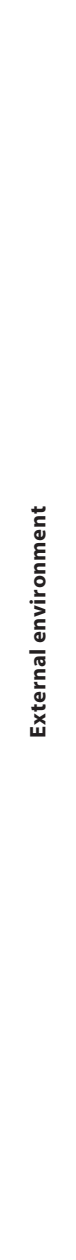 } & 139 & Government bond yield $2 \mathrm{Y}$ - Eurozone & $\%$ & CNB, ARAD & - & 1 & $\mathrm{~F}$ \\
\hline & 140 & Government bond yield $5 Y$ - Eurozone & $\%$ & CNB, ARAD & - & 1 & $\mathrm{~F}$ \\
\hline & 141 & Government bond yield 10Y - Eurozone & $\%$ & CNB, ARAD & - & 1 & $\mathrm{~F}$ \\
\hline & 142 & Yield spreads on risky private sector bonds & value & $\begin{array}{l}\text { CNB - Financial Stability } \\
\text { Report 2016/2017 }\end{array}$ & - & 2 & $\mathrm{~F}$ \\
\hline & 143 & Crude oil, Brendt, $\$ /$ bbl, current Europe & USD/barrel & EIA & - & 2 & $\mathrm{~F}$ \\
\hline & 144 & Crude oil, Brendt, \$/bbl, current US & USD/barrel & EIA & - & 2 & $\mathrm{~F}$ \\
\hline & 145 & Crude Oil Production, US fields & $\begin{array}{l}\text { thousand } \\
\text { barrels }\end{array}$ & EIA & - & 2 & $\mathrm{~F}$ \\
\hline & 146 & $\begin{array}{l}\text { Composite indicator of systemic stress, } \\
\text { Eurozone }\end{array}$ & index 0-1 & ECB & - & 1 & $\mathrm{~F}$ \\
\hline & 147 & EURIBOR 3M & $\%$ & $\mathrm{ECB}$ & - & 1 & $\mathrm{~F}$ \\
\hline & 148 & $\begin{array}{l}\text { GDP, chain index volumes, Eurozone (changing } \\
\text { composition) }\end{array}$ & $\begin{array}{l}\text { Index } 2010 \\
=100\end{array}$ & Eurostat & - & 2 & $\mathrm{~F}$ \\
\hline & 149 & DAX index & value & Datastream & - & 2 & $\mathrm{~S}$ \\
\hline & 150 & Industrial production index, total Germany & $\begin{array}{l}\text { Index } 2005 \\
=100\end{array}$ & Eurostat, ipp_st_m & - & 2 & $\mathrm{~S}$ \\
\hline & 151 & Ifo - Business Climate Index, Germany & $\begin{array}{l}\text { Index } 2005 \\
=100\end{array}$ & CESifo & - & 2 & $\mathrm{~S}$ \\
\hline & 152 & All Commodity Price Index & $\begin{array}{l}\text { Index } 2005 \\
=100\end{array}$ & IMF & - & 2 & $\mathrm{~S}$ \\
\hline & 153 & Non-Fuel Price Index & $\begin{array}{l}\text { Index } 2005 \\
=100\end{array}$ & IMF & - & 2 & $\mathrm{~S}$ \\
\hline & 154 & Food and Beverage Price Index & $\begin{array}{l}\text { Index } 2005 \\
=100\end{array}$ & IMF & - & 2 & $\mathrm{~S}$ \\
\hline & 155 & Industrial Inputs Price Index & $\begin{array}{l}\text { Index } 2005 \\
=100\end{array}$ & IMF & - & 2 & $\mathrm{~S}$ \\
\hline & 156 & Agricultural Raw Materials Index & $\begin{array}{l}\text { Index } 2005 \\
=100\end{array}$ & IMF & - & 2 & $\mathrm{~S}$ \\
\hline & 157 & Metals Price Index & $\begin{array}{l}\text { Index } 2005 \\
=100\end{array}$ & IMF & - & 2 & $\mathrm{~S}$ \\
\hline & 158 & Fuel (Energy) Index & $\begin{array}{l}\text { Index } 2005 \\
=100\end{array}$ & IMF & - & 2 & $\mathrm{~S}$ \\
\hline & 159 & Crude Oil (petroleum), Price index & $\begin{array}{l}\text { Index } 2005 \\
=100\end{array}$ & IMF & - & 2 & $\mathrm{~S}$ \\
\hline
\end{tabular}

\section{Source: Own processing}




\section{References}

Bai, J., Li, K., Lu, L. (2016). Estimation and Inference of FAVAR Models. Journal of Business \& Economic Statistics, 34(4), 620-641, https://doi.org/10.1080/07350015.2015.1111222

Bakk-Simon, K., Borgioli, S., Giron, C., Hempell, H., Maddaloni, A., Recine, F., Rosati, S. (2012). Shadow Banking in the Euro Area: An Overview. European Central Bank. Occasional Paper No. 133.

Barbu, T. C., Boitan, I. A., Cioaca, S. I. (2016). Macroeconomic Determinants of Shadow Banking - Evidence from EU Countries. Review of Economic and Business Studies, 9(2), 111-129, https://doi.org/10.1515/rebs-2016-0037

Beck, G. W., Kotz, H., Zabelina, N. (2016). Lost in Translation? ECB's Monetary Impulses and Financial Intermediaries' Responses. SAFE. White Paper Series 36.

Bernanke, B. S., Boivin, J., Eliasz, P. (2005). Measuring the Effects of Monetary Policy: A Factoraugmented Vector Autoregressive (FAVAR) Approach. The Quarterly Journal of Economics, 120(1), 387-422, https://doi.org/10.1162/0033553053327452

Boivin, J., Giannoni, M. P., Mihov, J. (2009). Sticky Prices and Monetary Policy: Evidence from Disaggregated US Data. American Economic Review, 99(1), 350-384, https://doi.org/10.1257/aer.99.1.350

Brunnermeier, M. K., Sannikov, Y. (2014). A Macroeconomic Model with a Financial Sector. American Economic Review, 104(2), 379-421, https://doi.org/10.2139/ssrn.2160894

Cecchetti, S., Mancini-Griffoli, T., Narita, M. (2017). Does Prolonged Monetary Policy Easing Increase Financial Vulnerability? IMF. Working Paper No. WP/17/65, https://doi. org/10.5089/9781484308363.001

Claessens, S., Ratnovski, S. (2014). What Is Shadow Banking? IMF. Working Paper No. 2P/14/25, https://doi.org/10.2139/ssrn.2559504

COM/STD/DAF (2015). Results of the Survey on Shadow Banking. Paris: Organization for Economic Cooperation and Development.

David, R., Šebesta, P. (2007). Securitization in the Czech Republic: the Legal Regime and Transactions to Date. [Retrieved 2017-09-10] Available at: http://www.globalsecuritisation. com/07_emea/DB07_241_246_Czech.pdf

Du, J., Li, CH., Wang, Y. (2016). A Comparative Study of Shadow Banking Activities of Non-Financial Firms in Transition Economies. China Economic Review, 46, S35-S49, https://doi.org/10.1016/j.chieco.2016.09.001

Duca, J. V. (2014). What Drives the Shadow Banking System in the Short and Long Run? Federal Reserve Bank of Dallas. Working Paper No. 1401, https://doi.org/10.24149/wp1401

EC (2012). Green Paper on Shadow Banking. Brussels: European Commission.

Eickmeier, S., Hofmann, B. (2013). Monetary Policy, Housing Booms and Financial (Im)Balances. Macroeconomic Dynamics, 17(4), 830-860, https://doi.org/10.1017/s1365100511000721

Forni, M., Gambetti, L. (2010). The Dynamic Effects of Monetary Policy: A Structural

Factor Model Approach. Journal of Monetary Economics, 57(1), 203-216, https://doi.org/10.1016/j.jmoneco.2009.11.009 
Frait, J., Malovaná, S. (2017). Monetary Policy and Macroprudential Policy: Rivals or Teammates? Journal of Financial Stability, 32(2), 1-16, https://doi.org/10.1016/j. jfs.2017.08.004

FSB (2011). Shadow Banking: Strengthening Oversight and Regulation. Recommendations of the Financial Stability Board.

FSB (2012). Global Shadow Banking Monitoring Report 2012. Financial Stability Board.

Hampl, M., Matoušek, R. (2000). Credit Contraction in the Czech Republic: Causes and Consequences. Czech National Bank. Working Paper No. 19.

Herman, A., Igan, D., Solé, J. (2017). The Macroeconomic Relevance of Credit Flows: An Exploration of U.S. Data. Journal of Financial Stability, 32, 124-141, https://doi. org/10.1016/j.jfs.2017.06.009

IMF (2014). Global Financial Stability Report 2014, Chapter 2: Shadow Banking around the Globe: How Large, and How Risky? [Retrieved 2017-09-10] Available at: https://www.imf.org/ external/pubs/ft/gfsr/2014/02/pdf/c2.pdf.

Kuc, M., Teplý, P. (2015). A Rollercoaster Ride of Czech Credit Unions. Procedia Economics and Finance, 25, 239-248. https://doi.org/10.1016/s2212-5671(15)00734-0

Moreira, A., Savov, A. (2017). The Macroeconomics of Shadow Banking. The Journal of Finance, 72(6), 2381-2432, https://doi.org/10.1111/jofi.12540

Nelson, B., Pinter, G., Theodoridis, K. (2017). Do Contractionary Monetary Policy Shocks Expand Shadow Banking? Journal of Applied Econometrics, 33(2), 198-211, https://doi. org/10.1002/jae.2594

OECD (2015). Regulation of Insurance Company and Pension Fund Investment. OECD Report to G20 Finance Ministers and Central Bank Governors.

Pozsar, Z., Adrian, T., Ashcraft, A., Boesky, H. (2013). Shadow Banking. Economic Policy Review, 19(2), 1-16.

Pozsar, Z., Singh, M. (2011). The Nonbank-Bank Nexus and the Shadow Banking System. IMF. Working Paper No. WP/11/289, https://doi.org/10.5089/9781463927233.001

Stock, J. H., Watson, M. W. (2002). Forecasting Using Principal Components from a Large Number of Predictors. Journal of the American Statistical Association, 97(460), 1167-1179, https://doi.org/10.1198/016214502388618960

Tuzcuoglu, K., Hoke, S. H. (2016). Interpreting the Latent Dynamic Factors by Threshold FAVAR Model. Bank of England. Working Paper No. 622, https://doi.org/10.2139/ssrn.2850442

Verona, F., Martins, M. M., Drumond, I. (2013). (Un)anticipated Monetary Policy in a DSGE Model with a Shadow Banking System. International Journal of Central Banking, 9(3), 73-117, https://doi.org/10.2139/ssrn.2256278

Woodford, M. (2010). Financial Intermediation and Macroeconomic Analysis. Journal of Economic Perspectives, 24(4), 21-44, https://doi.org/10.1257/jep.24.4.21 